\title{
Engineering commodifiable workers: language, migration and the governmentality of the self
}

\author{
Alfonso Del Percio ${ }^{1}$
}

Received: 25 October 2016/Accepted: 7 March 2017/Published online: 29 March 2017

(C) The Author(s) 2017. This article is an open access publication

\begin{abstract}
This article examines the strategies and forms of expertise on language and communication mobilized to engineer commodifiable migrant workers. Drawing on an ethnographic account of counselling practices in a state-run Italian job guidance centre for newly arrived migrants, I examine the calculations, tactics, and forms of expertise on language and communication mobilised by job counsellors. Here, I illustrate how these tactics regulate, or "police", migrants' communicational conduct and promote their socialisation into a desirable professional self that can be commodified on the Italian job market. In doing so, I demonstrate that the state's investment in the policing of migrants and the commodifiability of their labour is an investment in a larger project of societal consent for both the arriving migrants and for the forms of precarity they are believed to embody in Italy. At the same time, I argue this state agenda should not make us blind to the fact that the individuals and actors, including professional counsellors, working in these job guidance centres seem ready to invest a great deal into these spaces in the interest of pursuing another, more emancipated agenda. Indeed, in my paper I aim to demonstrate that job guidance centres are also spaces of hope where people work to support migrants who are preparing themselves for a viable future and attempting to create the practical framework for their life projects.
\end{abstract}

Keywords Language - Migration · Work · Commodification · Governmentality · Italy

Alfonso Del Percio

Alfonso.delpercio@gmail.com

1 Department of Culture, Communication \& Media, UCL Centre for Applied Linguistics, UCL Institute of Education, University College London, 20 Bedford Way, London WC1H 0AL, UK 


\section{Introduction}

Migration and employment have often been conceptualised by institutions and actors governing labour as deeply interconnected processes, with migration being used a means to regulate the supply of labour and solve problems of labour shortage (Duchêne et al. 2013). At the same time, along with their "national origin," the status of migrants (in terms of residency, citizenship, access to welfare, or family reunification) has been made dependent on the (imagined) productivity of their human capital (Vigouroux 2017). Categories such as "unskilled", "semi-skilled", "skilled", and "highly skilled", which assign workers to unequally valued positions in the larger structure of labour, have often served the transnational governmentality of migration (Allan and McElhinny 2017).

For many decades, European policy makers have believed that connecting the regulation of migration to work and employment policy satisfies the volatile demand for labour in national industries while also guaranteeing order and security in the migrants' countries of reception. Recently, however, the EU's labour market experts have expressed their concerns about the effects of the uncontrolled influx of "irregular" migrants to Europe, particularly questioning whether national labour markets have the capacity to absorb this surplus of ostensibly unskilled workers (EU 2015). Experts note that, in times of economic stagnation and large-scale unemployment, receiving poorly qualified, often illiterate, and sometimes traumatized individuals represents a burden for already strained national welfare systems and poses a challenge to social cohesion and peace (OECD 2015).

As a reaction to these governmental anxieties, the European Union and its member states have put in place a set of institutions, processes, and calculations promoting migrants' marketability on the European job markets (EU 2016). This has entailed the implementation of new social services provided by privately owned NGOs or corporate actors. This has also meant the reconceptualisation of preexisting established public services that, while traditionally directed toward domestic job seekers, have been asked to supply newly arrived migrants with a series of empowering actions and activities to help them sell their labour power in their host economies (OECD 2016).

The aim of this article is to examine the calculations, tactics, and forms of expertise on language and communication mobilised to engineer commodifiable migrant workers. By commodifiability I mean here the aptitude of migrants to transform their capacity to do work into a thing that, under specific structures of wages, could be exchanged with material forms of compensation. More specifically, I discuss the counselling practices I documented between July 2015 and April 2016 at a job guidance centre for newly arrived migrants. ${ }^{1}$ It is located in one of the major urbans centres of Italy - a country that has been greatly affected by the arrival of Asian and African migrants from the north African coasts due to its geographical location in Europe's southern borders.

\footnotetext{
1 This work was partly supported by the Research Council of Norway through its Centres of Excellence funding scheme, project number 223265.
} 
This article draws on ethnographic data (Smith 2005) involving detailed observations of counselling practices at the job guidance centre, casual conversations with both job counsellors and unemployed migrants, as well as institutional and legislative documents that entextualise the expertise on which the counselling practices rely. Other data include photographs and printed copies of job postings, as well as brochures and training materials produced, circulated, and consumed in the job guidance centre.

This article is structured as follows: I first situate my analysis in a linguistic scholarship interested in how the commodification of the labouring self is articulated with practices of linguistic policing. Second, I examine the specific mandate and mode of functioning of the job guidance centre and discuss the diverging agendas that these spaces serve. Third, I turn to an analysis of the everyday counselling practices of three counsellors-Patrick, Marco and Antonia. ${ }^{2}$ I particularly examine the micro-physical techniques and forms of knowledge on language, work, and the self that counsellors and migrants mobilise to promote the professional integration of migrants. I also document the tensions-between counsellors and migrants, as well as within the team of counsellors, and describe the challenges caused by regulating the conduct of migrants.

By doing so I demonstrate that, in the investigated job guidance centre, the commodifiability of migrants' labour power is imagined to depend from migrants' willingness to socialize themselves into a specific professional persona and communicational register that is said to raise their value on the labour market. I will also argue that while these job guidance centres are spaces where unemployed workers are asked to inhabit neoliberal subjectivities and are required to discipline their bodies and languages according to neoliberal principles of flexibility, competitiveness and entrepreneurialism, these are also spaces of hope, where both counsellors and unemployed migrants invest in forms of change and emancipation.

\section{Language, work, and commodification of the self}

Research in the field of language policy has dedicated extensive critical attention to the spaces and settings in which individuals are transformed into employable workers (Demazière and Glady 2011; Flubacher et al. 2017). Scholars have particularly studied the interactional and often highly regulated and standardised practices used by counsellors to support unemployed individuals (de Saint Georges 2011), and have furthermore examined the specialised registers produced by these professionals (Divay 2011). Sociolinguists have also questioned the measures implemented to manage linguistic diversity in the organisations and offices which promote migrants' professional integration (Codò 2013; Codò and Garrido 2014). Finally, research has problematised the role of these spaces in the valuation of migrants' linguistic competence (Bae 2014; Park and Wee 2012), and in the unequal access individuals have to valued resources such as language training and other

\footnotetext{
$\overline{2}$ The name of all individuals mentioned in this paper are pseudonyms.
} 
forms of education and skills acquisition (Duchêne 2016; Gao and Park 2015; SaidSirhan 2014).

In addition to this work, scholars on language and governmentality have taken job guidance centres as a point of entry to examine the forms of expertise which shape productive citizens (Del Percio 2016). Scholars have particularly noted that the disciplining activities required of unemployed individuals in job guidance centres are often informed by a specific form of knowledge on language and communication that converts them into speakers of a specific, morally and culturally marked register (Allan and McElhinny 2017; Lorente 2012). This change in communicational manner is generally imagined to help them meet the demands of future employers (Allan 2013, 2016). Scholars have further noted that this policing of communicational conduct draws on a meritocratic logic that assumes employment is a choice; that employment is dependent on an individual's willingness to optimise and flexibilise their self through the acquisition and internalization of those attitudes and tokens of knowledge that today's capitalism demands (Del Percio and Flubacher 2017; Martin-Rojo 2016). Governments and employers claim that constant self-regulation and self-realisation is the only viable way for an individual to remain competitive in an instable labour market (Sennett 1998; Urciuoli 2008). Consequently, work on the self would therefore represent the only way to gain access to social and economic emancipation and civic inclusion (Fraser 2003).

These regulatory practices and techniques specifically target unemployed migrants (Yeung and Flubacher 2016). Indeed, by echoing foundational work in sociolinguistics that identifies unshared communicational scripts as being at the base of miscommunication and failure of job interviews (see e.g. Gumperz and Roberts 1978; Gumperz et al. 1979; see also Gumperz 1982), employers, educators, and policy makers ask migrants to acquire the necessary linguistic and communicational templates that will support them in turning their professional selves into commodifiable labour power (Del Percio and Van Hoof 2017: Lorente 2010).

In what follows, I will discuss the ways migrants attempt to appropriate these communicative resources. Taking the aforementioned literature on language and communication as a starting point, I produce a detailed account of the communicative strategies and knowledge invested in job guidance centres which express control over migrants' communicative behaviour. In doing so, I will discuss the set of operations that unemployed individuals voluntary effect on their own bodies, thoughts, and communicational conduct with the goal of becoming desirable professional selves that can be commodified on specific labour markets.

\section{Turning migrants into entrepreneurial job seekers}

At the end of the 1990s, the Italian government established a national network of job guidance centres that are charged to assist citizens who are seeking employment, promote further learning and requalification amongst job seekers', and help people understand and benefit from information on the local job market. These job guidance centres were introduced as part of a larger reform of the country's labour legislation at the end of the 1990s. These changes involved the implementation of a 
series of measures facilitating the deregulation of work. Simultaneously, they legalised precarious and instable work contracts which, according to the political authorities, facilitated the creation of employment in times of economic stagnation. Within this changing legislative framework, the job guidance centres were seen as spaces where unemployed individuals could be supported in their (re)integration into this changing labour market. Job guidance centres were also considered to play a crucial role within a logic of lifelong learning; constant adaptability and flexibility of the working subject was said to be at the core of a sustainable and inclusive labour policy.

The small job guidance centre where I conducted the research is located in one of the poorest peripheries of a large Italian city. While the other centres of the city are addressed to a wider group of unemployed citizens, this guidance centre is exclusively dedicated to advising newly arrived migrants and refugees. The municipal government decided to dedicate one of the city's guidance centres to the specific needs of migrants in 2006, after public concerns had been raised about rising unemployment in the local migrant community and the local media had called attention to the local population's increasing sense of insecurity caused by unemployed migrants. The move aims to facilitate migrants' quick integration into the local, formal job market while simultaneously combatting forms of informal labour often associated with migrants in Italy.

Patrick, the centre's director and his team of three experienced job counsellors had all been very active in the promotion of the professional integration of migrants long before the municipality's decision to create a centre for migrants. Most of the team members had been working as counsellors in other centres of the city since the 1990s. Due to their experience with unemployed migrants and their activism in different NGOs and social cooperatives, the city's councillor for employment and vocational education selected them to be part of this new job guidance centre.

In one of the first conversations ${ }^{3}$ during our close collaboration, Patrick noted that, while all three counsellors are involved in all aspects of the work, each member of the team have developed a specific role and function. Antonia, for example, is responsible for the acquisition and management of potential employers. Job guidance centres do not officially provide employer-to-employee matching services but rather focus exclusively on promoting an individual's capacity to autonomously choose and manage their own professional trajectory. Nevertheless, in the past years, Patrick's team, and Antonia in particular, has developed an informal network of contacts with local employers to facilitate their clients' access to the labour market. Then there is Marco. He is responsible for monitoring the job market; they pin collections of job offerings on the centre's wall so that the clients can see and consult them. Marco also repairs and updates the old PCs and fixes the printers because the municipality has no money to replace old machines. Finally, Patrick, the team leader, is responsible for managing the group and maintaining contacts with important actors within the local administration, and the community of NGOs and cooperatives active in assisting and integrating the migrant population. In our

\footnotetext{
3 The conversations reported in this article draw on field-notes produced during the author's presence in the field between July 2015 and April 2016.
} 
conversations, Patrick stressed that none of team had been trained as job counsellors or social workers. All had learned their "craft," as Patrick calls it, on the job and rely on self-financed trainings and informal channels of information to remain up to date with new ways of supporting their clients. The local authorities see the investment in a job guidance centre dedicated exclusively to migrants as a way to demonstrate the municipality's ability to manage and control migration, thus enhancing security in the city and its peripheries. However, Patrick noted that his team is deeply motivated by a shared commitment to social change and wish to empower newly arrived migrants who lack a professional network in Italy. According to Patrick, they are concerned that newly arrived migrants are particularly vulnerable to processes of deskilling, labour exploitation, and unemployment, because they have such a poor understanding of the Italian language. Patrick emphasised that orienting migrants is not simply a profession, but a calling to provide individuals with essential tools and knowledge, thus helping them become self-sufficient actors on the job market.

To exemplify this idea of self-sufficiency, Patrick pointed out that a major problem of newly arriving migrants is that they do not know how to look for employment. Many are accustomed to an informal hiring system in which day labourers passively wait on a sidewalk for contractors to stop and hire them. These individuals must learn to function in a formal hiring system, where unemployed workers make the first step and actively approach a potential employer through a whole set of codified practices. However, in order to overcome the social stigma that Italian employers generally associate with the type of migrants Patrick's team usually works with (these individuals are from South Asia, the Middle East, Africa, and Eastern Europe), unemployed migrants - and unemployed individuals more generally-are asked to work on themselves, on how they present their professional person, and on their attitudes and conduct. The overarching goal is to enable them to sooner or later become self-sufficient workers able to take care of themselves and their families. Patrick added that this insistence on the responsabilisation of the unemployed individual represents a shift in job counselling, away from a diagnostic psychological model to a more empowering and activating model. In the 1960s and 1970s (i.e. during times of full employment), a counsellor was viewed as an expert of identifying and choosing the profession that best suits the personality of the job seeker through a series of personality tests. Now, due to the high precarisation and flexibilisation of work, counsellors are expected to focus on an individual's motivation, resilience, and optimism. Techniques are geared towards promoting a job seeker's capacity to take independent decisions and be responsible for their own professional success and personal well-being.

This shift in the counselling practice mentioned by Patrick is part of a larger transformation in the management and psychology of work in the 1980s that was interested in humanising and improving the worker conditions. Experts looked to move away from a management style drawing on forms of regulation and coercion, and towards a managerial doctrine which capitalises on worker's intuition, motivation, passion, and creativity (Gee et al. 1996). Participation and empowerment of the working self, as well as responsibility and self-esteem is assumed to contribute to the enhancement and quality of products (Rose 1999). This doctrine is 
accompanied by a portrayal of the entrepreneurial self that is mobilised in popular literature as well as business schools, vocational education, and professional reintegration programs such as those studied here (Gee et al. 1996; Rose 1999). This discourse integrates the view that everybody can be an entrepreneur and have success-if only he or she would learn the skills of self-inspection and selfrepresentation, and restyle his or her communicative behaviour, speech and vocabulary (also see Cameron 2000b).

The question I want to pursue in the next sections is how this idea of the entrepreneurial self becomes manifest in the everyday counselling practices of Patrick's team. What are the techniques used to interpellate (Althusser 2014) unemployed migrants as entrepreneurial job seekers and mobilized to raise the commodifiability of migrants' labour power? What problems, tensions and challenges do these regulatory practices cause-and for whom?

\section{Learning how to read the "market"}

The first time I entered the office of the job guidance centre, the walls in the major rooms attracted my attention. Each wall was entirely covered with printed job offerings. One wall was hung with job offers designated "catering industry" and "tourism"; another "housekeeping", "nurses", "security personnel"; and yet another "constructions", "logistics", and "other offers". Every Tuesday and Thursday, Marco scours through the national and local papers and pins printed job offers on the centre's wall, replacing the old offers, so that their clients can see and consult the adverts. A sample of these job offerings- those that Marco considers most suitable for the public of migrants they serve-are also placed on the large table situated in the centre of the reception room. Patrick told me that these walls represent the job market in the city. Every wall stands for a sector of the local economy, so that studying these walls and the posted offerings would give anyone a good idea of the dynamics of the local job market. According to Patrick, these walls are important to migrants because the posted offers enable them to familiarise them with the market's demands, its dynamics, and the types of positions available, as well as the qualities and skills that are valued by potential employers. Patrick contends that seeing what the market is looking for gives unemployed individuals hope. It helps them to adjust their strategies, and forces them to take the initiative; they can use it to facilitate their strategies and decisions to improve their access to the labour market. At the same time, these walls should also help counter unrealistic expectations in terms of job opportunities that some migrants have when they arrive in Italy-especially amongst those who held prestigious positions in their home countries and hope to be able to occupy their old position in their host country.

Nevertheless, Patrick maintains that the market is not a transparent entity. In order for migrants to become free and autonomous actors in the employment market, they must adopt a specific role to enable them to read the market, i.e. to understand and predict its functioning, logics and demands, and to submit themselves to its disciplining power. In this regard, working on one's self involves learning a whole set of techniques and strategies that enable a migrant to profit from 
the opportunities the local job market has to offer, as well as to understand what kind of person the market asks them to be. Patrick believes that having skills in reading the market is a precondition for a worker's ability to sell labour power in a formal, highly institutionalised, labour market that becomes intelligible exclusively through its textual manifestation in job ads. Because ignoring how to read the market would imply being automatically disqualified from the opportunities it has to offer. Every job seeker, independent of the profession he or she aspires to, is obliged to develop this analytical technique. The only alternative would mean having to gain access to a potentially costly network of gatekeepers to support them.

Accordingly, I observed that in the very first step in the centre's process, migrants were asked to learn reading the market and to familiarise with its demands. For example, Karim was a 21-year-old unemployed migrant from Mali who had already spent three years in Italy. However, following an initial interview during which their personal data were entered in the centre's database, Patrick asked Karim to sit at the big table situated in the centre of the main counselling room every other afternoon and independently go through the job ads pinned on the centre's walls. Marco insisted that, before starting to actively look for employment, Karim should become acquainted with these job ads, their structure, technical terminology, and content. He should also learn to quickly scan the large number of offers pinned on the guidance centre's walls and to differentiate between serious and non-serious job offers. He should train himself in understanding the specific tasks and operations that a future employee would be expected to perform, and in identifying the characteristics, skills, and qualifications required for every type of job. Karim should furthermore think about what additional training he would need to become a good candidate for the jobs that interest him. The job guidance centre has a small budget at its disposal for each of its clients; this money can be invested in short programs leading to certificates and qualifications that promote employability. Marco explained that Karim should come with an Italian-French dictionary (Karim is proficient in French) to translate the difficult words in the ads and, using a pen and a notebook, list the requirements and skills demanded for every type of job, while also noting the steps necessary to meet these requirements.

An initial look at how Patrick characterises the different operations that the unemployed individual is asked to perform helps us understand that learning how to read the market goes far beyond a simple practice of decoding job offers. Individuals have to understand, predict, anticipate as well as scan, differentiate, identify, reflect, translate, list, and take notes. Like a businessperson who engages in a market analysis in order to plan his or her next moves, the job seeker is constructed as an entrepreneur of the self, i.e. is asked to invest in an analytical habitus that will enable him or her to take certain decisions or actions and that will sooner or later be rewarded with employment and socioeconomic emancipation. I repeatedly heard this line of argument at the job guidance centre.

In the following days, Karim came to the centre and consulted the job offerings posted on the walls. He was particularly interested in employment in logistics and looked into job offers searching for personnel in the domain of loading and unloading goods. He was also interested in jobs as an unskilled worker in the construction industry. He followed Patrick's advice and, with the dictionary he was 
given at his reception centre, he independently identified the characteristics demanded for this type of employment. Sometimes he asked Patrick for clarifications or to help him with complicated syntactic structures such as "prior experience in the professional activity," difficult words such as "good logical capacities", or unintelligible abbreviations, such as DDT [ownership transfer certificate], that he was not able to translate with his dictionary. When Patrick was occupied with another client, Karim asked other counsellors or other, more experienced job seekers who were also consulting the job offers. He realized that while the bits and pieces of Italian and the experience he had acquired in the fruit markets of his hometown would serve him as assets for this specific job profile, he would first need to obtain a license to use the lift trucks that are used in the different storage rooms and logistic centres of the city. He would also have to undergo a specialised security training required by the Italian government for all employees in logistics.

"He is motivated, we will finance the training he needs, it is a good investment, his exemplary conduct will sooner or later help him to find a position", Patrick told me this after Karim had asked him to help him translate a sentence in a job offer for a position in one of the big fruit markets of the city. According to Patrick, not all unemployed migrants demonstrate this dedication and resilience; many refuse to work on themselves or make a careful analysis of the job market and its possibilities.

Indeed, during my presence in the field, I was able to observe how the counsellors' insistence on the necessity to work on one's ability to read the market (another frequently used phrase) often clashes with the migrants' need to find employment quickly. Many of the individuals using the centre's services are in urgent need of a job because they have to leave their reception centres. This is either because their asylum requests have been rejected and they are asked to leave the country, or because their requests have been accepted and the local authority have given them permission to find employment on the Italian labour market, meaning they are no longer entitled to receive asylum benefits. "I need to work." "Help me find a job." "I don't have time to waste." These are the recurrent claims of migrants who thus challenge the counsellors' strategies and call on them to act more vigorously as facilitators or to grant access to the privileged pool of contacts with local employers that the group of counsellors have at their disposal. However, this is exclusively reserved, so Patrick says, to persons who, like Karim, are particularly skilled and motivated. Patrick emphasised that the risk of disappointing employers with job candidates who would make a poor impression or fail to meet expectations and demands is too high. He explained that he would be putting an important contact at stake who could grant another migrant access to a job at some point in the future.

In other cases, however, another circumstance factored more highly than the migrants' unwillingness to internalise the counsellors' advice: the migrants' apparent lack of dedication and resilience is rooted in their inability to read the job offers. In one conversation with Patrick, he admitted that many clients at the job guidance centre are simply unable to read these job offers, mainly due to their poor skills in the Italian language. While many of the migrants, especially those who had just arrived, are fluent either in an international language such as English or French, 
their knowledge of Italian is not sufficient to allow them to independently read and understand these texts. In addition, many of these individuals are either illiterate or have been socialised in writing systems that differ from the Latin alphabet, an aspect that further complicates how they engage with the local labour market. Although the counsellors might advise them to take one of the many free Italian classes offered to newly arrived migrants in the city, thus helping them overcome the linguistic gap, many of them feel that investing time in language education clashes with their need to invest time and energy in finding employment. In several cases, this conflicting interest has actually led migrants to reject the counsellors' advice and recommendations concerning language skills.

As such, a paradoxical situation ensues. The counsellors at the job guidance centre view learning how to read the market as the first step towards the transformation of migrants into an empowered professional self, one able to sell his or her labour on the Italian job market. However, this assumption is perceived by many migrants as complicating their access to formal employment. Rather than causing them to question their traditional opinions about an informal labour market, the requirement to develop skills in a whole set of literacy techniques seems to push some migrants, particularly those with poor skills in Italian and those who most need employment, towards other, often informal channels of labour provision. By extension, this also contributes to the reproduction of their marginalized position in the larger structure of the labour market.

Patrick is aware of this situation and explained during one of the many lunch breaks we shared that clients frequently misunderstand the centre's function and objective. Although the centre has a certain number of contacts to local employers, its role is not to provide job seekers with a position, even if this were feasible in some cases. Matching employers with employees is the role of the local employment agency. The function of job guidance centres is to train migrants in becoming independent job seekers, i.e. to give people the tools and capabilities necessary to make good choices and independent decisions. Patrick said that even if he and his team wished to help everybody, their resources are restricted and they therefore need to focus on the main mission. They are simply not the right office for people who are in urgent need of employment yet unwilling to invest in themselves.

\section{Entextualising a "bundle of skills"}

One of the principle tasks in the counselling process of unemployed migrants is the production of their curriculum vitae (CV). Marco told me that, while the submission of a CV is a must, even for 'unskilled', manual labour, many migrants have neither the necessary literacy skills nor the actual equipment such as a computer and a printer to do justice to the form and scripted format that modern employers demand. Some of them, Marco noted, arrive with an old CV that a social worker or a volunteer they encountered over the course of their migration trajectory had prepared for them. But often these documents are outdated, full of spelling mistakes, and lacking clarity in terms of the candidate's professional background. In many cases, Marco reiterated, these documents are in bad shape, and the paper they are 
printed on is of poor quality, often dirty and creased, and thus unsuitable for a job application.

In Marco's opinion, a CV, however, is a potential employee's business card because it is a document that presents an overview of the professional experiences and technical abilities that compose the specific profile of an individual. A CV reveals a great deal about the character of an employee: their adaptability, independence, and flexibility, as well as their demeanour and way of communicating with customers and co-workers. Marco believes that a good CV not only permits an employer to quickly evaluate the value of a worker and his or her capabilities; it also enables the worker to assess their competence and the skills needed to gain access to the desired position or profession. Therefore, unemployed workers who lack qualifications and have only poor linguistic skills, and especially migrants such as those taking advantage of the centre's services, require support when creating this document. The CV can help them convincingly present their professional abilities, and thus aid them in rising above a subaltern position on the Italian labour market.

Marco's account of the CV and how these texts entextualise potential employees' qualities and capabilities is one instance of what Urciuoli (2008) calls 'skills discourses'. These discourses are a manifestation of a neoliberal rational that constructs each individual as "a summation of commodifiable bits" which can be acquired, assessed, and enhanced as well as marketed and sold. These discourses, Urciuoli argues, operate in and stand for a new, flexibilised and deregulated work order in which employees are seen as entrepreneurs of their selves. Employees should be individuals who make a specific set of investments in their own capabilities and become responsible for the market value of their labour. According to this logic, a CV is a hypertext that points to each element in a "bundle of skills" and creates the conditions for selling this bundle on a given labour market.

However, while Marco clearly participates in this specific skills discourse, and to a certain extent contributes to its implementation, he would never see himself as an actor endorsing neoliberal logics of the working self. In our conversations, it became clear that he entirely rejects the precarious working conditions that migrants are subjected to. He is also opposed to an idea of the self that can be reduced to a set of productive resources. His provision of expertise on the Italian job market and his advice on how to write a good CV in particular are, in his view, a way of helping migrants develop the necessary strategies and tools to navigate current labourmarket conditions - and indeed to challenge the related effects of exclusion.

During my presence in the job guidance centre, I observed how Marco and the other counsellors in the office use the Guideline Europass Curriculum Vitae to help migrants write a competitive CV. This is a 53-page manual produced by the EU's European Centre for the Development of Vocational Training that regulates the production of the so-called Europass CV. This is a standardized CV template promoted by the European Commission aimed at making European workers comparable among the member states, thus improving the mobility of Europe's workers. The overarching objective of the Guideline is to present a series of instructions on how to write a competitive CV. For instance, job seekers receive the following instructions: "Be clear, succinct and concise." "Use simple words and 
unambiguous language." "Use short sentences." "Avoid jargon and clichés." "Quantify your achievements." "Present your skills and competences logically." And "Pay attention to spelling and punctuation."

The document also stresses the importance of structure: "Put the most relevant information on your professional skills first in order to give to a reader a synthetic idea about the profile of the candidate and then list the work and training experience that shape your professional profile." And: "Highlight your strengths according to the needs of the employer and focus on the skills that match the job." Or: "Don't hesitate to remove old information if it does not add value for the position."

The Guideline also proposes fragments of discourse that the employment seeker, or the counsellors supporting them, can mobilise when compiling the CV. When referring to professional skills, candidates should mention "group work," "coordinate others," "coordinate oneself," "communicate (write correctly, transmit information in an efficient mode, present products, negotiate, be persuasive," "capacity of adaptability in multicultural work environments."

In other words, the Guideline is a discursive resource that can be mobilised strategically to create the "bundle of skills" that a CV is designed to entextualise. It is a template that helps a migrant transform their discontinuous life trajectory and highly precarious lifestyle into a token of a culturally and morally marked, qualified type of person that is held to be in demand on the European job market. Furthermore, as Marco notes, because these guidelines point to the qualities that an employable (i.e. commodifiable), professional persona is imagined to embody, this document also helps individuals examine their own professional subjectivity, meaning that it recalls the distance between what she or he is and what she or he should become. In those terms, I understand the process of self-examination scripted by the Guideline as a technology of the self (Foucault 1993) because it involves the acquisition of additional rules of conduct believed to shape a specific desirable subjectivity and to transform the unemployed subject into a commodifiable professional persona.

Marco explains that counsellors play a crucial role in a migrant's self-reflection. The team spends three to four sessions helping the unemployed migrants reconstruct their professional trajectory, assess their competencies and qualities, and enxtextualise these in a CV. This reconstruction and assessment of their professional self, a practice of self-reflection that the counsellors technically call "assessment of competencies", often confronts counsellors and unemployed migrants alike with a whole set of communicative challenges. The "assessment of competencies" carried out by Marco with Reza, a 40-year-old migrant from Iran, is emblematic of the difficulties that this specific practice poses, and representative of the strategies the counsellors develop to cope with these challenges. The first two sessions in which Marco and Reza tried to co-construct Reza's professional trajectory were characterized by major communication problems. Although Reza had developed quite a high level of fluency in Italian in the two years he had spent in the country, it seemed to me that what complicated the reconstruction of Reza's professional background were differing understandings of what counts as work. Reza considered work to include taking care of a family member, farm work, or helping out in his brothers' business. But Marco hesitated to include these activities in the CV. Marco 
and Reza tried to involve other counsellors, who were also in the midst of a counselling session, in order to negotiate which activities were counted as work and which should be counted as leisure. After long negotiations, all participants agreed that farm work and helping out in Reza's brothers' family business is work, while taking care of a family member is not.

Another challenge that Marco encountered during the entextualisation of the "assessment of competencies" was placing his various professional experiences in chronological order so as to produce the impression of a coherent professional trajectory. Reza had worked on his family farm; when he was student he had worked as a tee cooker; he worked at his brother's carpet stand; he was active as a confectioner for many years; and in Egypt, on his way to Italy, he worked on construction sites. In the process of coherently ordering Reza's professional activities, Marco explained that, even if employers seem to currently desire flexibility, candidates also need to be able to strategically order their experiences so as to produce a coherent professional self, thus enabling them to claim expertise in the specific job they are applying for. Because Reza was aiming for employment in one of the local patisseries or bakeries, Marco decided to boost Reza's profile as an expert of pastries and bread. He did so by replacing Reza's work experience on different Egyptian construction sites with an invented professional activity as a baker.

The third challenge that counsellors encounter when entextualsing migrants' skills and experiences into a $\mathrm{CV}$ is the production of specialised professional registers denoting the type of activities, abilities, and expertise that a potential candidate holds. According to Marco, when listing the work experiences of the candidates, the employers also want to get an idea of the type of activities that the candidate was responsible for. This gives the potential employer an understanding of the tasks he or she is able to perform, and the type of machines and infrastructure the worker is able to operate and use. During the consulting sessions with Reza, I observed how Marco particularly struggled with this part of the CV. While he had managed to create a coherent professional trajectory transforming Reza into a competitive candidate for the specific job he wanted to apply for, Marco had difficulties finding the correct terminology for the activities Reza had performed in his different occupations. Marco explained, with slight embarrassment, that it is almost impossible to master all the jargon related to different professions - and that he can't cook. He explained that in such situations he generally finds a source of inspiration in a booklet at the centre that describes the profiles and professional activities of the most common professions. He is particularly interested in the different verbs commonly used in Italian bakeries to denote the different tasks these individuals are asked to perform. This, Marco claimed, would help Reza sound like a professional. He found: "to blend", "to knead", "to mix", "to combine ", "to decorate", and "to prepare". He also found valuable information about the different techniques and modalities bakers use when preparing their products such as "baking", "frying", and "bain-marie"; all words that Marco strategically integrated into his descriptions so as to make sure that Reza's account of his self would sound professional.

Despite the strong investment made by the counsellors in assessing migrants' capacities and experiences and in entextualising them into CVs, in the months I followed this team's work, a CV prepared in this way very seldom lead to actual 
employment. Migrants at this job guidance centre tend to find employment through their own informal contacts or contacts they receive from Patrick's team. Reza, for example, never found a job based on his CV. Instead, he was employed by one of his Iranian friends who owns a fruit stand at one of the city's farmer's markets. Most of the employers with whom he is in contact on a regular basis, Patrick says, claim that their clients are not ready for a foreign worker, especially if this worker has another skin colour or looks Arabic. In his experience, employers often do not trust the qualifications of foreign workers, especially if these are not certified with references, diplomas, or other documents that the migrants are generally unable to provide.

Patrick nevertheless believes that writing a CV is one of the main services that his team will provide in the future. Firstly, because it works in certain cases: some particularly skilled migrants are able to use their CV to find employment, especially in the informatics and telecommunication sector or in tourism. And second, because in order to penetrate the formal employment market, the formal application procedure that includes writing a convincing $\mathrm{CV}$ cannot be ignored. By consequence, if migrants want to become free agents on the Italian labour market they must not only learn the rules and techniques, but also the dangers and difficulties related to this specific document. As such, they must be trained to write a $\mathrm{CV}$, even if many of them lack the communicative competence to do so. This in turn, Patrick argues, motivates them to work on their Italian skills, which in turn increases their chances of finding work.

\section{Speaking like a professional}

A third crucial activity characterising the everyday engineering of commodifiable migrant workers in the Job guidance centre is preparing migrants for job interviews. In our conversation, I learned that Antonia is responsible for training the candidates who are invited for a job interview with an employer from the pool of privileged contacts she has within the local economy. Specifically, her task is to ensure that these individuals make a good impression. Normally when one of these employers contacts the office looking for an employee, she proposes four or five candidates from the list of unemployed migrants supported at the Job guidance centre to go to the employer for a job interview. The method of presenting a list of candidates instead of proposing only one promising individual, Antonia explained, is a way to give the organisation the possibility to choose the candidate that best suits their requirements and demands. On the other hand, the fact that several individuals contend for one position is a way to accustom the migrants to the highly competitive Italian labour market. Antonia believes that preparing a candidate for the job interview is a crucial step, especially because migrants do not often know the codes that characterise this specific communicative situation. Although most migrants using the services of the Job guidance centre have extensive professional experience, many of them have never gone through such a process. "Because they are unsure of how to act and what to say", she maintained, "they often freeze, seem timid, and therefore relay the impression of being insecure". In Antonia's opinion, all this is accentuated by their difficulties in expressing themselves in Italian and in 
understanding the interviewer. Carefully preparing the individuals for what they should expect at a job interview in terms of structure of the interview, the questions that will emerge, and the typical answers can help migrants feel more secure and improve their chances to gain employment. Antonia told me that making sure the migrants make a good impression also ensures that employers continue to consider the job guidance centre as a reliable source of labour provision.

In the summer of 2015, I watched Antonia prepare four migrants from Bangladesh, Syria, Egypt, and Bulgaria, respectively, for an interview for a position as a trainee in a small tailor shop in the city centre. Traineeships are usually the first step for migrants to gain access to a formal position with a regular contract. Because traineeships are partly or, in certain cases, fully financed by the state, these positions are often used by businesses to solve problems of staff shortages by gaining access to cheap labour. Migrants using the services of the job guidance centre, who often have extensive work experience and are ready to withstand precarious, quasi exploitative regimes of work, are considered to be ideal candidates for these jobs. According to Antonia, choosing young, unexperienced, Italian wannabe tailors would imply that the employer needs to invest time and money in training and education. However, migrants with work experience promise a flexible workforce that can contribute to the profitability of the tailor's business from day one.

The four candidates chosen by Antonia for the position in the tailor's shop had extensive experience as tailors in their home countries, some owning their own tailor workshop, and others having gained their first work experience in other tailor shops in Italy. The four candidates were individually prepared for their interview. According to Antonia, the preparation had to be adapted to the needs of the individual. While most of the counselling activities are conducted in the main room of the centre's office, this individual training usually takes place in a smaller room in which Patrick has his desk, and where the team spends its breaks and lunch time. Antonia calls this is a delicate moment in the counselling process. Migrants realise that much is at stake and they usually prefer face-to-face counselling sessions over group meetings. In group sessions, migrants have to expose their vulnerabilities and insecurities and are confronted with other candidates applying for the same position. Therefore, Antonia prefers seeing them separately.

The concrete counselling practices provided by Antonia are designed to transform the four selected migrants into ideal candidates, and are characterised by a mix of theoretical insights and practical exercises. One of the candidates, Mohammed, was a man in his thirties and had come from Syria where he had owned his own small tailor shop before the war. He allowed me to follow his entire preparation process, and here he was advised to work first on his physical appearance. Although trainees in tailor's shops often work in a small chamber that is invisible to customers, Antonia explained that employers like to hire people who are careful about their appearance. She instructed Mohamed to shave on the day of his interview and to take a shower. During the various counselling sessions, Mohamed had often appeared with a scruffy beard, Antonia explained to me after Mohamed had left to smoke. Because the reception centre where he is staying doesn't offer the possibility to shower every day, it was important that he could arrange the possibility to wash up on the day of the interview. He also had to find appropriate 
clothes for the interview. She told him not to dress up, but to make sure that his clothes were clean and his shirt ironed.

Then Antonia gave advice about how to behave during the interview. She asked Mohamed to note the following instructions on a piece of paper:

- "speak in a calm manner without interrupting the employer's questions";

- "explain your answers and talk in a precise manner about the things you have done";

- "actively participate in the interview by asking for clarifications and asking questions";

- "make eye contact with the employer";

- "show you are able to control anxiety and emotions, for example, don't rub your hands, don't touch your face and hair";

- "when you leave, thank the employer for his time".

She explained to Mohamed that these instructions are rules of conduct that are not valid exclusively for migrants and refugees but also for Italian job applicants. She furthermore pointed out that, since these situations are particularly complicated for people like Mohamed who struggle with language (Mohammed had been working in different jobs in the local, informal labour market and had not yet been able to attend one of the language classes offered by the Italian authorities to arriving refugees), having a few rules of conduct in mind can be reassuring. "Employers do not only want you to be professional and skilled", Antonia told Mohamed. "You should also be sociable, self-confident, interested, motivated, and engaged, and at the same time calm and focused". She stressed that this is what employers want and what Mohamed has to give them to get the job.

Antonia asked Mohamed to internalise these instructions and conducted several practice interviews with him. She asked him to learn to talk about his past professional experience, his skills and qualifications, and the reasons why he had chosen to apply for this specific traineeship. During the interaction, she repeatedly commented on his facial expressions, she asked him to smile more, to avoid nervously jiggling his knee, to place his hands on the table and avoid moving them too much, and to try to be clearer in the description of the specific tasks he had performed in his tailor shop in Syria. In order to help him sound more convincing, Antonia printed a list of basic technical terminology that he had to memorize such as "collar", "ribbon", "scissors", "chalk", "pocket", "sleeve", "zipper" and "canvas", but also more complicated terms, as she said, such as "mannequin", "lace", "embroidery", "paillettes", "double-breasted coat", "tacking", and "fringe". She said this would enable him to speak with his potential employer about what he had done in past and about the tasks that he would have in future. She also advised him to memorise the most common brands of sewing machines-Bernina, Brother, Singer, Necchi, Toyota-and to try to remember the brands of the machines that he used in Syria. "This", she explained me, "will show that he knows the principle tools used in this profession, thus proving that his work experience is genuine".

In other words, Antonia asked Mohamed to internalise and reproduce a communicative register that, in her opinion, would help authenticate his professional 
experience (Lorente 2010). Through the acquisition of a list of concepts and brand names pertaining to the shared knowledge of Italian tailors, he would familiarise himself with the professional discourse unique to sewing in Italy which would enable him to be recognised as a legitimate member of the imagined community of Italian tailors. At the same time, Antonia also asked Mohammed to work on himself to control his emotions, regulate his body, and discipline his communicative delivery. As such, Antonia believes becoming a desirable professional implies not only being recognised as a knowledgeable member of a professional community, but also having the ability to enact a specific persona that adopts a whole set of culturally scripted rules and norms of social behaviour standing for personal stability and mental health.

However, while Patrick's team conceptualise the kind of work that Antonia asks Mohamed to do as a form of skilling and empowerment of the unemployed self, I would argue that these trainings are rather what Cameron (2000a) calls practices of styling the communicative conduct of migrants. As Cameron explains, while skilling involves both the acquisition of practical expertise about how to do things as well as knowledge about why things are the way they are, the communicational trainings provided by Antonia are rather concerned with the management of the acceptability of the job candidates' speech. Indeed, while observing Antonia preparing Mohammed for his job interview, I realised that he did not fully understand the specific logics underpinning the communicative instructions he was asked to internalise. He mechanically reproduced the instructions provided to him. There was no acquisition of language going on, but rather what Cameron calls an aesthetic "grooming on the surface" (Cameron 2000b: 86) of Mohammed's communicative behaviour.

So it is not surprising that Mohammed had evident difficulties in appropriating the requested communicative script. Nevertheless, he followed Antonia's instructions and tried to memorise the list of concepts she had given him. He asked Antonia for another counselling session so that they could practice the interview. Mohamed also called his family in Syria to make sure that the sewing machines brands he had in mind were the correct ones. Then he talked to one of the social workers at his reception centre to ensure that, on the day of the interview, he could actually use the centre's bathroom so as to have the possibility to shower and shave. Finally, he made sure to find a pair of new trousers and a shirt, as he felt the clothing he owned was not appropriate for such an important event. In other words, he internalised the assumption that his possibility to gain access to this specific position depended on his motivation and capacity to reproduce the kind of persona that Antonia had asked him to be.

In spite of his efforts and dedication, Mohammed was not offered the position in the tailor shop. The job was instead given to another of the four candidates who, according to Antonia, had a better command of Italian and who therefore had been able to convince the employer of his qualities. Although, professionally speaking, Mohammed was probably the most qualified of the four candidates, Antonia believes his poor language skills and his high levels of insecurity, caused by the unstable situation he and his family currently experience as newly arrived migrants in one of city's reception centres, probably disqualified him very early on in the job interview. The fact that Mohammed's interview was much shorter than the others is a sign that the employer had very quickly decided against him. According to Antonia, the importance of language is not related to its role in the productive 
process of the tailor shop because the future employee is not expected to have any customer contact or to communicate with other stakeholders. The actual work that these employees are asked to do is strictly manual: they are employed solely to contribute to the sewing and tailoring process. Nevertheless, a candidate's capacity to speak the language is perceived by the employers as a sign of social integration and adaptability, and as an indication of the candidate's general aptitude to follow specific rules and norms. "Migrants who cannot speak the language", she says, "are seen as individuals who have failed to meet the demands of their countries of reception and therefore as workers who sooner or later will cause trouble and pose a risk to order and productivity in the workshop".

\section{Conclusion}

In this article, I have taken the everyday routines of three counsellors as a point of entry to understand the practices and strategies mobilised by Italian job guidance centres to raise the commodifiability of migrants' labour power. For this process, I argue that language and communication are key resources, yet not necessarily because they act as objects of commodification (Heller and Duchêne 2016; Heller 2010). Rather, I have demonstrated that, together with other highly scripted modes of behavioural conduct, specific modes of speaking, listening, writing, and reading are seen by the professional counsellors as powerful tools that potentially enable individuals to package the "bundle of skills" that migrants should sell on the labour market. Language and communication are also resources which enable them to stage their capacity to be flexible and adaptable, and to fashion and refashion their selves according to the demands of changing and highly fluctuating work situations and professional requirements. In other words, the migrants learn to adapt themselves as an object of commodification to the needs and expectations of a potential buyer and to eventually raise the desirability of their labour power on specific economic markets.

Through a detailed description of the microphysical practices and tactics mobilised to fabricate commodifiable migrant workers, I have also shown that that this policing of behaviour and communicational conduct is one that posits the unemployed self as the agent of his or her own disciplining and regulation. Critically, the here documented regulation of the unemployed self and its language fundamentally differs from the disciplinary and coercive power that Fordist institutions exerted onto individuals and societies. The Italian state investment in the engineering of commodifiable migrants is rather emblematic of a sort of neoliberal governmentality that extends market principles of competitiveness, flexibility, adaptability, and efficiency to the management of individuals and that capitalises on the subject's willingness and aspirations to be free and successful (Foucault 1993). Following this line of reasoning, Rose and Miller (2010) have argued that the type of neoliberal governmentality documented in this article can be characterised as occurring "at a distance" because it operates through voluntary acts. Here, we see it operate through migrants' voluntary investment in their personal ambition for economic independence. Furthermore, it operates at a distance because this form of policing eschews violence and oppression, instead drawing on a whole set of 
expertise and principles on language, work, and the self. These principles cause people to believe that the operations they are asked to exert on their own body, language, and beliefs is for their own good, and that these processes will lead them to a skillset that will grant them access to employment and freedom.

Despite the investment in these practices of self-policing, the commodification of migrants' labour power remains complicated in Italy. During my fieldwork, only very few individuals seemed able to capitalise on the linguistic and professional knowledge acquired during the counselling sessions. Many migrants preferred searching for employment on the informal labour market, where they can profit from their personal networks and their capacity to make the best out of a difficult situation; a skill they have developed over the course of their lives (see Vigouroux 2013 for a discussion of this cultural capital in the South African context). Yet the local state authorities persist in considering support offered to migrants in job guidance centres as the most promising strategy to achieve professional integration. This is partly because, in times of economic instability and high unemployment rates, the state's investment in professional counselling enables them to communicate-both to the migrants and to a wider, international audience of humanitarian actors concerned with the sort of individual arriving in Europe - that the Italian state cares for these, and is able to safeguard their welfare and guarantee their integration. In addition, the state's investment in job guidance centres is a means to shift responsibility for the integration and socioeconomic emancipation of migrants to the unemployed migrants themselves, while also fostering the illusion that professional integration is possible if they continue working on themselves. Finally, the state's investment in a policy of supporting unemployed migrants sends a message to the local Italian population, who have been contesting the migrants' presumed unconditional access to the Italian welfare system. They have demanded that the Italian state is required to pursue stricter migration policies, including benefit cuts and rigorous sanctions for those who refuse to take responsibility for their access to labour or to take the necessary steps to integrate in the local community.

Nevertheless, this reported state agenda and the documented (self-)disciplining power of the service provided by job guidance should not obscure the fact that individuals and actors, including professional counsellors and the migrants themselves, seem ready to invest in these centres in the interest of pursuing another, more emancipated agenda. Indeed, in this paper I have tried to demonstrate that although job counsellors tend to reproduce and naturalise neoliberal rationales of the working subject, they never seem to fully buy into these discourses. Rather, they strategically use these rationales in order to support migrants in preparing themselves for a viable future, and in creating the practical conditions for their life projects. It is certainly true that job guidance centres occupy a crucial place in the larger state infrastructure to sustain the neoliberal economy (with its contradictions, inequalities and exclusive effects) (Del Percio et al. 2016) and contribute to the shaping of the kind of neoliberal subjectivities which maintain capitalist growth. But these spaces also need to be seen as spaces of hope (Harvey 2000), where people work-albeit with minimal successon a daily basis to form alternative lives.

Open Access This article is distributed under the terms of the Creative Commons Attribution 4.0 International License (http://creativecommons.org/licenses/by/4.0/), which permits unrestricted use, 
distribution, and reproduction in any medium, provided you give appropriate credit to the original author(s) and the source, provide a link to the Creative Commons license, and indicate if changes were made.

\section{References}

Allan, K. (2013). Skilling the self: The communicability of immigrants as flexible labour. In A. Duchêne, M. Moyer, \& C. Roberts (Eds.), Language, migration and social inequalities: A critical sociolinguistic perspective on institutions and work (pp. 56-78). Bristol: Multilingual Matters.

Allan, K. (2016). Self-appreciation and the value of employability: Integrating un(der)employed immigrants in post-fordist Canada. In L. Adkins \& M. Dever (Eds.), The post-fordist sexual contract. Living and working in contingency (pp. 49-70). Basingstoke: Palgrave Macmillan.

Allan, K., \& McElhinny, B. (2017). Neoliberalism, language and migration. In S. Canagarajah (Ed.), The Routledge handbook on language and migration. New York: Routledge.

Althusser, L. (2014). On the reproduction of capitalism: Ideology and ideological state apparatuses. New York: Verso.

Bae, S. (2014). Anxiety, insecurity and complexity of transnational educational migration among Korean middle class families. Journal of Asian Pacific Communication, 24(2), 152-172.

Cameron, D. (2000a). Styling the worker. Journal of Sociolinguistics, 4(3), 323-347.

Cameron, D. (2000b). Good to talk: Living and working in a communication culture. London: Sage.

Codò, E. (2013). Trade unions and NGOs under neoliberalism: Between regimenting migrants and subverting the state. In A. Duchene, M. Moyer, \& C. Roberts (Eds.), Language, migration and social inequalities (pp. 25-55). Bristol: Multilingual Matters.

Codò, E., \& Garrido, M. R. (2014). Shifting discourses of migrant incorporation at a time of crisis: Understanding the articulation of language and labour in the Catalan nongovernmental sector. International Journal of Multilingualism, 11(4), 1-20.

De Saint Georges, I. (2011). Les dynamiques langagières de l'accompagnement. Langage et société, 137(3), 47-74.

Del Percio, A. (2016). The governmentality of migration: Intercultural communication and the politics of (Dis)placement. Language \& Communication, 51, 87-98.

Del Percio, A., \& Flubacher, M. (2017). Language, education and neoliberalism: Critical studies in sociolinguistics. In M. Flubacher \& A. Del Percio (Eds.), Language, education, and social neoliberalism. Bristol: Multilingual Matters.

Del Percio, A., Flubacher, M., \& Duchêne, A. (2016). Language and political economy. In O. Garcia, N. Flores, \& M. Spotti (Eds.), Oxford Handbook of language in society (pp. 55-75). New York: Oxford University Press.

Del Percio, A., \& Van Hoof, S. (2017). Enterprizing migrants: Language, education and the politics of activation. In M. Flubacher \& A. Del Percio (Eds.), Language, education, and neoliberalism. Bristol: Multilingual Matters.

Demazière, D., \& Glady, M. (2011) (Eds.). Les discours de l'accompagnement: nouvelles normes du retour à l'emploi. Langage et société 137(3).

Divay, S. (2011). Une progressive rationalisation de l'encadrement des chômeurs. Langage et société, 137(3), 91-111.

Duchêne, A. (2016). Investissement langagier et économie politique. Langage et société, 157(3), 79-96.

Duchêne, A., Moyer, M., \& Roberts, C. (Eds.). (2013). Language, migration and social (in)equalities. Bristol: Multilingual Matters.

EU. (2015). Work and social welfare for asylum seekers and refugees. Strasbourg: European Parliamentary Research Service.

EU. (2016). Labour market integration of refugees: Strategies and good. Brussels: Directorate General for Internal Policies.

Flubacher, M., Coray, R., \& Duchêne, A. (2017). Language investment and employability. London: Palgrave Pivot.

Foucault, M. (1993) About the beginning of the hermeneutics of the self: Transcription of two lectures in Darthmouth on Nov. 17 and 24, 1980. In Blasius, M. (Ed), Political theory, Vol. 21(2), May, 1993, (pp. 198-227).

Fraser, N. (2003). From discipline to flexibilization? Rereading foucault in the shadow of globalization. Constellations, 10(2), 160-171. 
Gao, S., \& Park, J. (2015). Space and language learning under the neoliberal economy. L2 Journal, 7(3), 78-96.

Gee, J., Hull, G., \& Lankshear, C. (1996). The new work order. Boulder, CO: Westview.

Gumperz, J. (1982). Discourse strategies. New York: Cambridge University Press.

Gumperz, J., Jupp, T., \& Roberts, C. (1979). Crosstalk: A study of cross-cultural communication. Southall: National Centre for Industrial Language Training in Association with BBC.

Gumperz, J., \& Roberts, C. (1978). Developing awareness skills for inter-ethnic communication. Southall: National Centre for Industrial Language Training.

Harvey, D. (2000). Spaces of hope. Edinburgh: Edinburgh University Press.

Heller, M. (2010). The commodification of language. Annual Review of Anthropology, 39, 101-114.

Heller, M., \& Duchêne, A. (2016). Treating language as an economic resource: Discourse, data, debates. In N. Coupland (Ed.), Sociolinguistics: Theoretical debates (pp. 139-156). New York: Cambridge University Press.

Lorente, B. (2010). Packaging English-speaking products: Maid agencies in Singapore. In H. KellyHolmes \& G. Mautner (Eds.), Language and the market (pp. 44-55). NewYork: PalgraveMacMillan.

Lorente, B. (2012). The making of "workers of the world": Language and the labour brokerage state. In A. Duchene \& M. Heller (Eds.), Language in late capitalism (pp. 183-206). New York: Routledge.

Martin-Rojo, L. (2016). Neoliberalism and linguistic governmentality. In O. Garcia, N. Flores, \& M. Spotti (Eds.), Oxford handbook of language in society. New York: Oxford University Press.

OECD. (2015). How will the refugee surge affect the European Economy?. Paris: OECD Publishing.

OECD. (2016). Making integration work. Paris: OECD Publishing.

Park, J., \& Wee, L. (2012). Markets of English: Linguistic capital and language policy in a globalizing world. New York and London: Routledge.

Rose, N. (1999). Governing the soul: The shaping of the private self. London: Free Associations Books.

Rose, N., \& Miller, P. (2010). Political power beyond the state: Problematics of government. The British Journal of Sociology, 61(1), 271-303.

Said-Sirhan, Y. (2014). Linguistic insecurity and reproduction of the Malay community's peripherality in Singapore. Journal of Asian Pacific Communication, 24(2), 221-240.

Sennett, R. (1998). The corrosion of character: The personal consequences of work in the new capitalism. New York: W.W. Norton.

Smith, D. (2005). Institutional ethnography: A sociology for people. Oxford: AltaMira Press.

Urciuoli, B. (2008). Skills and selves in the new work place. American Ethnologist, 35(2), 211-228.

Vigouroux, C. (2013). Informal economy and language practice in the context of migrations. In A. Duchêne, M. Moyer, \& C. Roberts (Eds.), Language, migration and social inequalities: A critical sociolinguistic perspective on institutions and work (pp. 296-328). Bristol: Multilingual Matters.

Vigouroux, C. (2017). Rethinking (Un)skilled migrants: Whose skills, what skills, for what and for whom? In S. Canagarajah (Ed.), The Routledge handbook on language and migration. New York: Routledge.

Yeung, S., \& Flubacher, M. (2016). Discourses of integration: Language, skills, and the politics of difference. Multilingua, 35(6), 599-616.

Dr. Alfonso Del Percio is Lecturer in Applied Linguistics at UCL Institute of Education, University College London. He was trained in the fields of critical sociolinguistics and linguistic anthropology. His ethnographic and discourse analytic research deals with the intersection of language and political economy and focuses on language, migration and governmentality, the links between language, work, and social inequality. He also investigates the commodification of multilingualism and linguistic diversity under late capitalism. The outputs of Alfonso's research have appeared in books published by Routledge, Bloomsbury, and Suhrkamp as well as in peer-reviewed journals such as Pragmatics and Society, Social Semiotics, Signs and Society, Anthropologie et Sociétés, Applied Linguistics Review, and Language and Communication. 